\title{
Mechanisms of hepatoprotective effects of white and black garlic extracts against preneoplastic lesions induced by $\mathrm{N}$-nitrosodiethylamine in rats
}

\author{
Mostafa Abbas Shalaby $^{1^{*} \oplus}$, Rehab Ali Gandour $^{\circledR}{ }^{\circledR}$ Shimaa Ramadan Emam $^{1}{ }^{\circledR}$ \\ ${ }^{1}$ Department of Pharmacology, Faculty of Veterinary Medicine, Cairo University, Giza, P.O. Box 12211, Egypt \\ ${ }^{2}$ Department of Physiology, Faculty of Veterinary Medicine, Cairo University, Giza, P.O. Box 12211, Egypt
}

\section{A R T I C L E IN F O}

Article Type:

Original Article

\section{Article History:}

Received: 5 May 2021

Accepted: 23 July 2021

\section{Keywords:}

Garlic

N-nitrosodiethylamine

Serum analysis

Antioxidant

Tumor biomarkers

Histopathology

\begin{abstract}
A B S T RAC T
Introduction: Garlic has many pharmacological properties such as antibacterial, antiinflammatory, and antioxidant activities. This study aimed to investigate the possible mechanisms of the hepatoprotective effect of white garlic extract (WGE) and black garlic extract (BGE) against preneoplastic lesions induced by $\mathrm{N}$-nitrosodiethylamine (NDEA) in rats.

Methods: Forty-two rats were randomly distributed into six equal groups. Oral administration of WGE and BGE began 3 weeks before injection of NDEA. Group 1 was kept as negative control, while the other groups were injected by a single intraperitoneal dose of NDEA in the $3^{\text {rd }}$ week, followed by 2 subcutaneous injections/week of CCl4 till six weeks to induce preneoplastic lesions. Group 2 kept positive control and groups 3, 4, 5 and 6 were given WGE and BGE each of them at 250 and $500 \mathrm{mg} / \mathrm{kg}$, respectively, for six weeks from the beginning. Serum liver enzymes, total protein, albumin (Alb), total bilirubin (TBil), and antioxidant enzymes were measured. Malondialdehyde (MDA), glutathione (GSH), tumor biomarkers, along with the content of 8-hydroxy-2-deoxyguanosine (8-OHdG) in liver DNA were estimated and liver histopathology was performed.

Results: WGE and BGE significantly decreased the serum liver enzymes, TBil, tumor biomarkers, lipid peroxidation but increased total protein levels. The extracts significantly increased antioxidant enzymes, decreased 8-OHdG content in liver DNA, and alleviated histopathological lesions in the liver.

Conclusion: The results affirm the hepatoprotective effect of WGE and BGE against NDEAinduced preneoplastic lesions in rats. This effect may be due to inhibition of lipid peroxidation, reduction of tumor biomarkers, enhancement of antioxidant enzymes, or reduction of 8-OHdG content in liver DNA.
\end{abstract}

Implication for health policy/practice/research/medical education:

White and black garlic extracts produce a good protective effect against N-nitrosodiethylamine-induced preneoplastic lesions in rats. This effect might be due to inhibition of lipid peroxidation, increased activity of antioxidant enzymes or reduction of 8-OHdG content in liver DNA. Therefore, they might be useful in these subjects.

Please cite this paper as: Shalaby MA, Gandour RA, Emam SR. Mechanisms of hepatoprotective effects of white and black garlic extracts against preneoplastic lesions induced by N-nitrosodiethylamine in rats. J Herbmed Pharmacol. 2021;10(4):436442. doi: 10.34172/jhp.2021.51.

\section{Introduction}

Hepatocellular carcinoma is one of the most frequent malignant tumors and the second most common cause of deaths in developing and developed countries (1). Exposure to environmental carcinogens is an important risk factor leading to the formation of hepatocarcinoma. $\mathrm{N}$-nitrosodiethylamine (NDEA) is one of the most important environmental carcinogens that induces preneoplastic lesions in man and animals and is used as an experimental carcinogen (2-4). Because of serious side effects of synthetic anticancer drugs, the search for safe natural anticancer agents is necessary. Garlic (Allium sativum) is a popular vegetable, which is rich in bioactive organosulfur compounds such as allicin, alliin, diallyl disulfide, diallyl trisulfide, and S-allyl cysteine $(5,6)$. Black garlic is a type of fermented garlic prepared under high 
temperature $\left(65^{\circ} \mathrm{C}\right)$ and high moisture for 40 to 60 days. It is more effective and bitter than raw white garlic because it contains more antioxidants (contains more twice than white garlic) and more content of S-allyl cystine (7). In folk medicine, garlic and its bioactive compounds are used for the treatment of cardiovascular diseases and hypertension $(8,9)$, hypercholesterolemia, diabetes mellitus (10), and bacterial infections (11). Garlic is also used for the prevention of many types of cancers $(6,12-14)$, boosting immunity $(15,16)$, reduction of inflammation $(17,18)$ and oxidative stress $(19,20)$. Although the anticancer activity of garlic was reported in previous studies, the mechanisms underlying this activity are still not fully understood and need further investigations. The purpose of this study was to explore the possible mechanisms of hepatoprotective effect of each of white garlic extract (WGE) and black garlic extract (BGE) at two doses (250 and $500 \mathrm{mg} / \mathrm{kg}$ ) for 6 weeks against NDEA- induced preneoplastic lesions in rats.

\section{Materials and Methods \\ Garlic}

White and black garlic (Allium sativum, Family, Alliaceae) heads were purchased from a local grocery store in Egypt. The black garlic was purchased as food berry black garlic. The outer peels of the heads of both garlic types were removed and garlic cloves were minced into small pieces, powdered, and freeze-dried. The dried garlic powders were kept in a refrigerator until ethanol extraction.

\section{Chemicals and kits}

N-nitrosodiethylamine (Synonym: Diethyl nitrosamine, Product number: N0258, Molecular formula: $\mathrm{C}_{4} \mathrm{H}_{10} \mathrm{~N}_{2} \mathrm{O}$, NDEA) is a yellow liquid dispensed in $1 \mathrm{ml}$ ampoules. It was purchased from Sigma-Aldrich Chemical Company (St. Louis, MO, USA). Carbon tetrachloride (CCl4) was purchased from El-Gomhoryia Company, Egypt, in the form of a colorless solution. Enzyme-linked immunosorbent assay (ELISA) kits for the determination of alpha fetoprotein (AFP), tumor necrosis factor-alpha (TNF- $\alpha$ ), and nuclear factor-kappa B (NF-kB) were obtained from Glory Science Co., Taiwan.

\section{Rats}

Forty-two adult male Sprague-Dawley rats (180-190 $\mathrm{g}$ b. wt and 8-10 weeks old) were used in this study. Animals were obtained from the Laboratory Animal House, Agricultural Research Center, Egypt. Rats were housed in a well-ventilated controlled laboratory room under hygienic conditions of $24^{\circ} \mathrm{C}$ temperature, $50-52 \%$ relative humidity, and 12 hours light/12 hours dark cycles. Animals were fed on commercial rat pellets, purchased from Egypt Food Company, $6^{\text {th }}$ October, Egypt and water was provided ad libitum.
Preparation of garlic ethanol extract

The dried garlic powders (500 g of each type) were soaked in $1 \mathrm{~L}$ of $70 \%$ ethanol to obtain $25 \%$ concentration from each type and then kept in a refrigerator for 5 days with shaking every day. The liquid extracts were then condensed using a Rotary evaporator at $50^{\circ} \mathrm{C}$ temperature to evaporate and separate ethanol. The obtained semisolid extract was dissolved in Tween 80 solution to prepare the required dose for the rat.

\section{Induction of preneoplastic lesions}

The hepatic preneoplastic lesions were induced by a single intraperitoneal injection of NDEA at $100 \mathrm{mg} / \mathrm{kg}$ dissolved in dimethyl sulfoxide (DMSO) in the $3^{\text {rd }}$ week of the experimental period. This was followed by weekly two subcutaneous injections of $\mathrm{CCl} 4$ diluted with liquid paraffin (1:1), which was given in the $4^{\text {th }}, 5^{\text {th }}$, and $6^{\text {th }}$ week till the end of the experiment period. Each of WGE and BGE was orally given at 250 and $500 \mathrm{mg} / \mathrm{kg}$ from the beginning of experiment until six weeks.

\section{Experimental design}

The experiment was performed on forty-two adult Sprague-Dawley rats randomly distributed into six groups of seven rats each. Administration of each of WGE and BGE was started 3 weeks before NDEA administration. Group 1 was negative control, while the other groups were injected by a single intraperitoneal dose of NDEA in the $3^{\text {rd }}$ week of the experiment, followed by 2 subcutaneous injections/week of $\mathrm{CCl} 4$ till the 6 weeks to induce preneoplastic lesions. Group 2 was positive control and groups 3, 4, 5, and 6 were given each of WGE and BGE orally at 250 and $500 \mathrm{mg} / \mathrm{kg}$, respectively, for successive six weeks. At the end of the experiment, the rats were euthanized by prolonged exposure to ether and blood samples were withdrawn from the orbital plexus of the eye without addition of anticoagulant for separating the serum. The serum samples were centrifuged at $9000 \mathrm{rpm}$ for 10 minutes and kept frozen at $-70^{\circ} \mathrm{C}$ until biochemical analysis. Rats were sacrificed and half of the livers were used for preparing tissue homogenates to be used for tissue lipid peroxidation, antioxidant status and content of 8-OGdG in the liver DNA. The other half of the livers were preserved in $10 \%$ neutral formalin solution until processed for the histopathological examination.

\section{Biochemical analysis}

Serum aspartate aminotransferase (AST), alanine aminotransferase (ALT) (22) and alkaline phosphatase (ALP) (23) of the liver enzymes were chemically determined using specific kits. Serum total protein (TP) was chemically determined (24). Serum albumin (Alb) and globulins (Glb) were determined according to the method of Fernandez et al (25). Serum total bilirubin (TBil) and serum AFP levels were determined as 
previously described $(26,27)$. Serum levels of TNF-alpha were quantified as described by Pennica et al (28), and nuclear factor-kappa beta (transcription factor) levels were quantified as described by Adams (29) using ELISA kits (Glory Science Company, Taiwan) according to the instructions.

Assessment of liver antioxidant enzymes

One gram of frozen liver tissue was washed with icecooled $0.9 \% \mathrm{NaCl}$ solution and homogenized in $100 \mathrm{~mL}$ of ice-cooled $1.5 \%$ potassium chloride solution and $50 \mathrm{mmol}$ potassium phosphate buffer solutions ( $\mathrm{pH} 7.4$ ) to yield $1 \%$ homogenate $(\mathrm{W} / \mathrm{V})$. Liver homogenates were centrifuged at $4000 \mathrm{rpm}$ for 10 minutes at $4^{\circ} \mathrm{C}$. The supernatants were used for the estimation of lipid peroxidation (a final product of lipid peroxidation) as described by Ohkawa et al (30). The technique is based on the reaction of thiobarbituric acid with malondialdehyde (MDA) in acidic media at $95^{\circ} \mathrm{C}$ for 45 minutes to form thiobarbituric acid reactive substance (TBARS) and expressed as MDA content. Glutathione (GSH) content in liver homogenate was also determined (31). The activities of antioxidant enzymes glutathione peroxidase (GPx) (32), superoxide dismutase (SOD) (33), and catalase (CAT) (34) were colorimetrically determined. The tissue levels of MDA, GSH, GSPx, SOD, and CAT were chemically assayed using commercial assay kits.

\section{Quantification of 8-OHdG in liver DNA}

Genomic DNA in the liver was extracted from frozen liver tissues using a commercial DNeasy tissue kit. The contents of 8-OHdG in liver DNA were determined using Boster's competitive ELISA assay. Currently, 8-OHdG is widely accepted as a sensitive marker of oxidative DNA damage and oxidative stress. Evidence shows that increased content of $8-\mathrm{OHdG}$ is closely correlated with exposure to harmful environmental factors. Briefly, both 8-OHdG antibody and the sample were added to ELISA reading plate that had been coated with a fixed amount of coating $8-\mathrm{OHdG}$ antigen. The content of $8-\mathrm{OHdG}$ in the sample competes with the 8-OHdG antibody binding sites in the plate. The average content of $8-\mathrm{OHdG}$ in $\mathrm{ng} / \mathrm{mL}$ of liver DNA for each group was calculated. Samples of DNA assays were performed in vitro in duplicate (35).

\section{Histopathological assessment}

The other half of the livers were preserved in $10 \%$ neutral formalin solution. The fixed specimens were trimmed, washed, and dehydrated in ascending grades of alcohol. Tissue specimens were then cleared in xylene, embedded in paraffin, sectioned at 4-6 microns thickness, stained with Hematoxylin and Eosin (H\&E stain), and examined under a light microscope (36).

\section{Statistical analysis}

Data were presented as means \pm SE (standard error).
The statistical analysis was carried out using one way analysis of variance (ANOVA) test followed by Tukey test for multiple comparisons. The statistical program used in this study was SPSS (Statistical Package for the Social Sciences),+ computerized program version 17.0 (dated 2008). Significances between groups were tested at probability level $P<0.05$.

\section{Results}

Injection of NDEA significantly $(P<0.05)$ increased the serum levels of AST, ALT, and ALP enzymes compared to the negative control group. Oral administration of WGE at 250 and $500 \mathrm{mg} / \mathrm{kg}$, and BGE at the same doses for 6 weeks to NDEA-intoxicated rats significantly $(P<0.05)$ decreased AST, ALT, and ALP serum levels compared to the positive control group (Table 1).

Rats intoxicated by NDEA had significant $(P<0.05)$ decreases in serum TP, Alb, and Glb and an increase in TBil levels compared to the negative control group. Oral administration of WGE and BGE, each of them at 250 and $500 \mathrm{mg} / \mathrm{kg}$ for 6 weeks, to NDEA-intoxicated rats significantly $(P<0.05)$ reversed serum levels of TP, Alb, Glb, and TBil compared to the positive control group (Table 2).

Rats injected with NDEA had significantly $(P<0.05)$ increased serum levels of AFP, TNF- $\alpha$ and NF- $\kappa$ B compared with the negative control group. Oral administration of WGE and BGE, each of them at 250 and $500 \mathrm{mg} / \mathrm{kg}$ for 6 weeks to NDEA-intoxicated rats, significantly $(P<0.05)$ decreased the serum levels of tumor biomarkers (AFP, TNF- $\alpha$ and NF- $\kappa B$ ) compared to the positive control group (Table 3 ).

Rats intoxicated with NDEA had significant $(P<0.05)$ high content of hepatic MDAand low content of GSH when compared with the negative control group. Oral administration of WGE and BGE, each of them at 250 and $500 \mathrm{mg} / \mathrm{kg}$ for 6 weeks to NDEA-intoxicated rats, significantly $(P<0.05)$ reversed hepatic contents of MDA

Table 1. Effects of white garlic extract (WGE) and black garlic extract (BGE) on serum levels of aspartate aminotransferase (AST), alanine aminotransferase (ALT), and alkaline phosphatase (ALP) enzymes in rats intoxicated by NDEA

\begin{tabular}{lccc}
\hline \multirow{2}{*}{ Groups } & \multicolumn{3}{c}{ Parameters } \\
\cline { 2 - 4 } & AST (IU/L) & ALT (IU/L) & ALP (IU/L) \\
\hline Negative control & $45.0 \pm 1.16^{\mathrm{d}}$ & $40.0 \pm 2.21^{\mathrm{d}}$ & $89.5 \pm 3.15^{\mathrm{d}}$ \\
Positive control & $83.0 \pm 2.33^{\mathrm{a}}$ & $60.0 \pm 1.54^{\mathrm{a}}$ & $99.0 \pm 2.17^{\mathrm{a}}$ \\
WGE $(250 \mathrm{mg} / \mathrm{kg})$ & $77.0 \pm 1.13^{\mathrm{b}}$ & $54.0 \pm 2.43^{\mathrm{b}}$ & $53.0 \pm 1.56^{\mathrm{b}}$ \\
WGE $(500 \mathrm{mg} / \mathrm{kg})$ & $75.0 \pm 2.62^{\mathrm{b}}$ & $51.0 \pm 2.61^{\mathrm{b}}$ & $52.0 \pm 2.11^{\mathrm{b}}$ \\
BGE $(250 \mathrm{mg} / \mathrm{kg})$ & $55.0 \pm 1.42^{\mathrm{c}}$ & $42.0 \pm 1.44^{\mathrm{c}}$ & $45.0 \pm 1.56^{\mathrm{c}}$ \\
BGE $(500 \mathrm{mg} / \mathrm{kg})$ & $49.0 \pm 2.15^{\mathrm{c}}$ & $39.0 \pm 2.72^{\mathrm{c}}$ & $42.0 \pm 2.35^{\mathrm{c}}$ \\
\hline
\end{tabular}

Means \pm SEM in the same column with different superscript letters ( $a$, $b, c, d$ ) are significant at $P<0.05$ using one way ANOVA test. While those with similar superscript letters are non-significant $(n=7)$. 
Table 2. Effects of white garlic extract (WGE) and black garlic extract (BGE) on serum levels of total proteins (TP), albumin (Alb), globulin (Glb), and total bilirubin (TBil) in rats intoxicated by NDEA

\begin{tabular}{|c|c|c|c|c|}
\hline \multirow{2}{*}{ Groups } & \multicolumn{4}{|c|}{ Parameters } \\
\hline & $\mathrm{TP}(\mathrm{g} / \mathrm{dL})$ & Alb (g/dL) & Glb (g/dL) & TBil (g/dL) \\
\hline Negative control & $8.50 \pm 0.05^{a}$ & $4.14 \pm 0.14^{\mathrm{a}}$ & $3.40 \pm 0.10^{\mathrm{a}}$ & $0.38 \pm 0.01^{d}$ \\
\hline Positive control & $5.55 \pm 0.07^{c}$ & $2.25 \pm 0.12^{d}$ & $1.90 \pm 0.02^{\mathrm{d}}$ & $2.48 \pm 0.03^{a}$ \\
\hline WGE (250 mg/kg) & $6.43 \pm 0.03^{c}$ & $2.30 \pm 0.13^{c}$ & $2.60 \pm 0.04^{b}$ & $2.31 \pm 0.01^{c}$ \\
\hline WGE (500 mg/kg) & $6.43 \pm 0.03^{c}$ & $2.87 \pm 0.16^{c}$ & $2.65 \pm 0.01^{b}$ & $1.77 \pm 0.02^{b}$ \\
\hline BGE (250 mg/kg) & $7.80 \pm 0.05^{b}$ & $3.50 \pm 0.11^{b}$ & $3.00 \pm 0.02^{c}$ & $0.99 \pm 0.01^{c}$ \\
\hline BGE $(500$ mg/kg) & $8.30 \pm 0.04^{b}$ & $4.00 \pm 0.21^{b}$ & $3.10 \pm 0.01^{\mathrm{c}}$ & $056 \pm 0.02^{c}$ \\
\hline
\end{tabular}

Means \pm SEM in the same column with different superscript letters $(a, b, c, d)$ are significant at $P<0.05$ using one way ANOVA test, while those with similar superscript letters are non-significant $(n=7)$.

Table 3. Effects white garlic extract (WGE) and black garlic extract (BGE) on serum levels of alpha fetoprotein (AFP), tumor necrosis factor- alpha (TNF- $\alpha$ ), and nuclear factor-kappa beta (NF-KB) in rats intoxicated by NDEA

\begin{tabular}{|c|c|c|c|}
\hline \multirow{2}{*}{ Groups } & \multicolumn{3}{|c|}{ Parameters } \\
\hline & AFP (ng/mL) & TNF- $\alpha$ (ng/mL) & NF-kB (ng/mL) \\
\hline Negative control & $3.14 \pm 0.01^{d}$ & $1.95 \pm 0.01^{\mathrm{d}}$ & $19.0 \pm 3.11^{d}$ \\
\hline Positive control & $8.34 \pm 0.08^{a}$ & $4.82 \pm 0.07^{a}$ & $84.5 \pm 8.57^{a}$ \\
\hline WGE (250 mg/kg) & $6.12 \pm 0.04^{b}$ & $3.65 \pm 0.01^{b}$ & $56.4 \pm 6.38^{b}$ \\
\hline WGE (500 mg/kg) & $5.93 \pm 0.05^{b}$ & $3.45 \pm 0.02^{b}$ & $52.6 \pm 5.42^{b}$ \\
\hline BGE $(250$ mg/kg) & $4.22 \pm 0.02^{\mathrm{c}}$ & $2.76 \pm 0.02^{\mathrm{c}}$ & $35.0 \pm 7.01^{c}$ \\
\hline BGE (500 mg/kg) & $3.45 \pm 0.01^{c}$ & $2.20 \pm 0.01^{c}$ & $20.5 \pm 5.21^{c}$ \\
\hline
\end{tabular}

Means \pm SEM in the same column with different superscript letters $(a, b, c, d)$ are significant at $P<0.05$ using one way ANOVA test, while those with similar superscript letters are non-significant $(n=7)$.

and GSH compared to the positive control group (Table 4).

Activities of hepatic antioxidant enzymes GPx, superoxide dismutase (SOD), and CAT in NDEAintoxicated rats were significantly $(P<0.05)$ suppressed compared with the negative control group. Oral administration of WGE and BGE, each of them at 250 and $500 \mathrm{mg} / \mathrm{kg}$ for 6 weeks to NDEA-intoxicated rats, significantly $(P<0.05)$ increased activities of hepatic GPx, SOD, and CAT enzymes compared with positive control

Table 4. Effects of white garlic extract (WGE) and black garlic extract (BGE) on hepatic malondialdehyde (MDA) and reduced glutathione (GSH) contents in rats intoxicated by NDEA

\begin{tabular}{|c|c|c|}
\hline \multirow[b]{2}{*}{ Groups } & \multicolumn{2}{|c|}{ Parameters } \\
\hline & $\begin{array}{c}\text { MDA } \\
\text { ( } \mu \mathrm{mol} / \mathrm{g} \text { protein) }\end{array}$ & $\begin{array}{c}\text { GSH } \\
(\mu \mathrm{mol} / \mathrm{g} \text { protein })\end{array}$ \\
\hline Negative control & $45.32 \pm 0.3^{d}$ & $11.50 \pm 0.61^{\mathrm{a}}$ \\
\hline Positive control & $88.54 \pm 0.6^{a}$ & $5.62 \pm 0.25^{d}$ \\
\hline WGE $(250 \mathrm{mg} / \mathrm{kg})$ & $68.32 \pm 0.7^{b}$ & $7.22 \pm 0.51^{c}$ \\
\hline WGE (500 mg/kg) & $66.92 \pm 0.6^{b}$ & $7.89 \pm 0.42^{c}$ \\
\hline BGE $(250$ mg/kg) & $57.32 \pm 0.4^{b}$ & $9.62 \pm 0.65^{c}$ \\
\hline BGE (500 mg/kg) & $48.21 \pm 0.5^{c}$ & $10.72 \pm 0.62^{c}$ \\
\hline
\end{tabular}

Means \pm SEM in the same column with different superscript letters (a, $b, c, d$ ) are significant at $P<0.05$ using one way ANOVA test, while those with similar superscript letters are non-significant $(n=7)$. group (Table 5).

The content of apoptosis and oxidative stress biomarker 8-hydroxy-2-deoxyguanosine (8-OHdG) in liver DNA was significantly $(P<0.05)$ increased from 30 to $70 \mathrm{ng} / \mathrm{ml}$ as compared to normal control rats. Oral administration of WGE at 250 and $500 \mathrm{mg} / \mathrm{kg}$ and BGE at the same doses to NDEA-intoxicated rats for 6 weeks significantly $(P<0.05)$ decreased the content of $8-\mathrm{OHdG}$ to $55,50,45$, and $40 \mathrm{ng} / \mathrm{mL}$ DNA, respectively compared to $70 \mathrm{ng} / \mathrm{mL}$ DNA in the positive control group (Figure 1).

Histopathological examination (Figure 2) of liver sections of normal control rats showed normal histological architecture of hepatic lobule with normal hepatocytes and portal vein (Figure 2A). Liver sections of rats injected with NDEA showed trabecular preneoplastic lesions (long arrow) with fat droplets (short arrow) in tumor cells (Figure 2B). Other sections revealed compact hepatocarcinoma (long arrow) with fat globules in tumor cells and enlarged nuclei (short arrows) (Figure 2C). Polymorphism of the nuclei (short arrows) and the nuclei occupied most of the cell and increased cell mitosis (long arrow) (Figure 2D). Liver sections of the rats given orally the large $(500 \mathrm{mg} / \mathrm{kg})$ dose of WGE showed marked regression of preneoplastic lesions caused by NEDA, and only a few fat droplets were seen (Figure 2E). The large dose of BGE showed amelioration of preneoplastic lesions and only few fat droplets were seen (Figure 2F). 
Table 5. Effect of white garlic extract (WGE) and black garlic extract (BGE) on activities of hepatic glutathione peroxidase (GPx), superoxide dismutase (SOD), and catalase (CAT) in rats intoxicated by NDEA

\begin{tabular}{lccc}
\hline \multirow{2}{*}{ Groups } & \multicolumn{3}{c}{ Parameters } \\
\cline { 2 - 4 } & GPx (nmol/min/mg protein) & SOD (U/mg protein) & CAT (nmol/min/mg protein) \\
\hline Negative control & $64.10 \pm 4.21^{\mathrm{a}}$ & $0.85 \pm 0.04^{\mathrm{a}}$ & $0.192 \pm 0.03^{\mathrm{a}}$ \\
Positive control & $49.22 \pm 2.15^{\mathrm{d}}$ & $0.37 \pm 0.01^{\mathrm{d}}$ & $0.145 \pm 0.01^{\mathrm{d}}$ \\
WGE $(250 \mathrm{mg} / \mathrm{kg})$ & $53.13 \pm 3.23^{\mathrm{c}}$ & $0.52 \pm 0.02^{\mathrm{c}}$ & $\mathbf{0 . 1 7 0 \pm 0 . 0 2 ^ { \mathrm { c } }}$ \\
WGE $(500 \mathrm{mg} / \mathrm{kg})$ & $56.16 \pm 3.35^{\mathrm{c}}$ & $0.54 \pm 0.01^{\mathrm{c}}$ & $0.177 \pm 0.03^{\mathrm{c}}$ \\
BGE $(250 \mathrm{mg} / \mathrm{kg})$ & $59.23 \pm 4.73^{\mathrm{b}}$ & $0.73 \pm 0.03^{\mathrm{b}}$ & $0.181 \pm 0.02^{\mathrm{b}}$ \\
BGE $(500 \mathrm{mg} / \mathrm{kg})$ & $61.34 \pm 4.52^{\mathrm{b}}$ & $0.79 \pm 0.02^{\mathrm{b}}$ & $0.189 \pm 0.03^{\mathrm{b}}$ \\
\hline
\end{tabular}

Means \pm SEM in the same column with different superscript letters $(a, b, c, d)$ are significant at $P<0.05$ using one way ANOVA test, while those with similar superscript letters are non-significant $(n=7)$.

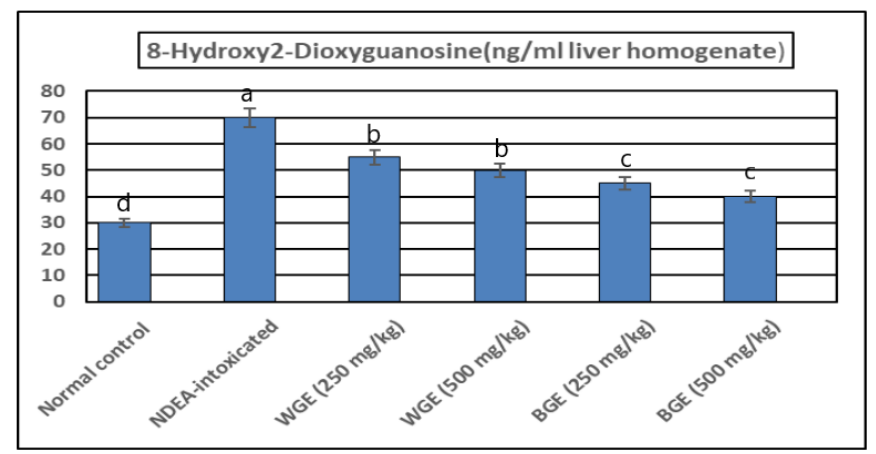

Figure 1. The content of 8-OHdG in liver DNA after oral administration of white garlic extract (WGE) at 250 and $500 \mathrm{mg} / \mathrm{kg}$ and black garlic extract (BGE) at the same doses for 6 weeks compared to the positive control group $(n=7)$.

\section{Discussion}

This research aimed to investigate the possible mechanisms of hepatoprotective effect of WGE and BGE against preneoplastic lesions-induced by NDEA in rats. In this study, NDEA and $\mathrm{CCl} 4$ were used to induce preneoplastic lesions experimentally in the liver of rats (4). CCl4 is a selective hepatotoxic chemical agent that is used for induction of hepatitis, oxidative stress, and liver damage in rats (37). It produces reactive free radicals, which initiate cell damage by induction of lipid peroxidation. Lipid peroxidation is associated with hepatic cell damage and leads to liver damage and fibrosis. Antioxidants succeeded in protecting against CCI4 hepatotoxicity or through attenuation of inflammation (38).
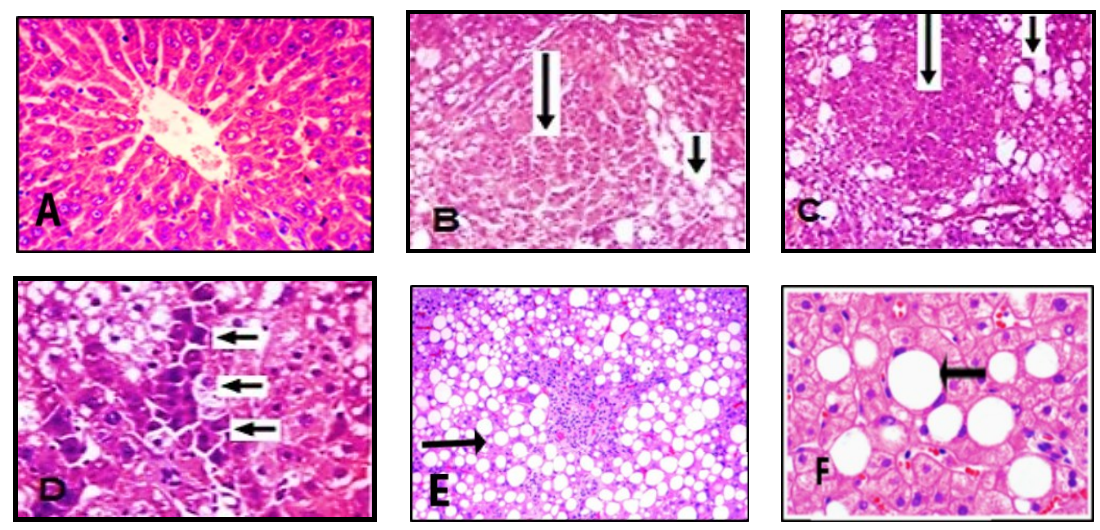

Figure 2. (A) Cross section (C.S.) of a liver of a control rat showing normal histological structure of hepatic lobule; (B) Rat intoxicated with NDEA showing trabecular preneoplastic lesions with fat droplets in tumor cells; (C) compact preneoplastic lesions with fat droplets and polymorphism of nuclei of hepatocytes; (D) Rat given orally the large dose of WGE showing marked regression of preneoplastic lesions and only few fat droplets were seen; (E) Rat given orally the large of BGE showing amelioration of preneoplastic lesions induced by NDEA and only few fat droplets were seen in (F). NDEA means $\mathrm{N}$-nitrosodiethylamine. 
Intoxication of the rats by NDEA and CCL4 induced preneoplastic lesions manifested by high serum levels of liver enzymes (AST, ALT, and ALP), TBil, tumor markers (AFP, TNF- $\alpha$, and NF- $\kappa \mathrm{B}$ ), and lowered total serum protein, albumin, and globulin levels. There were also increased hepatic lipid peroxidation, the content of 8-OHdG in liver DNA, and decreased activities of antioxidant enzymes. These serum and tissue biochemical alterations were parallel to preneoplastic lesions seen upon the examination of liver sections $(12,35,39)$. The previous authors concluded that intoxication of rats with NDEA and CCL4 induces preneoplastic lesions.

In rodents, garlic and its constituents have been reported to inhibit the development of chemically induced tumors in the liver (39). Oral administration of WGE and BGE exhibited a hepatoprotective activity against preneoplastic lesions in rats. In this study, hepatoprotection was manifested by decrease of liver enzymes, TBil, and regression of preneoplasticlesions. These findings agreed in some extent with those previously reported $(20,35,39,40)$. The previous authors concluded that garlic powder, oil, and the isolated functionally active compounds from garlic could be used for the prevention of preneoplastic lesions. Other authors explained the protective effect of garlic due to its antioxidant compounds, especially in aged black garlic $(18,19,40)$. The hepatoprotective effect of garlic was attributed to its ability to inhibit lipid peroxidation and tumor biomarkers $(39,40)$.

BGE exhibits several advantages when compared with fresh garlic. Black garlic is more effective and bitter than raw white garlic because it contains more antioxidants (contains more twice than white regular garlic) and more content of S-allylcysteine (7). The results of the hepatoprotection of BGE reported in the present study were in agreement with the previous studies $(7,20)$. Moreover, alterations in serum and tissue biochemical parameters induced by WGP and BGP were parallel to the alleviation of histopathological preneoplastic lesions seen in liver of NDEA-intoxicated rats. The histopathological findings seen in the present study were in accordance with the previously reports using garlic powders $(39,40)$, allyl sulphides (12), black aged garlic extract (7), or garlic oil $(14,20)$.

In conclusion, the results of this study highlight the possibility that WGE and BGE can cause potential protective effects against liver preneoplastic lesions in rats. These data could partially explain the hepatoprotection of garlic due to inhibition of lipid peroxidation, decreased levels of tumor biomarkers, increased activities of antioxidant enzymes, and decreased content of 8-OHdG in hepatic DNA.

\section{Acknowledgments}

The authors wish to thank Prof. Dr. Adel M. Bakeer, Professor of Pathology, Faculty of Veterinary
Medicine, Cairo University, Egypt for his comments on histopathological work. Sincere thanks are also offered to Mr. Ahmed Elshabrawy, technician of Pharmacology Department for his caring and feeding of rats.

\section{Authors' contribution}

MAS suggested the idea of this research and designed the work, RAG and SRE performed the experimental part of this work and wrote the first draft of the manuscript. All Authors shared writing, reading, revising and approval of the manuscript.

\section{Conflict of interests}

The authors declare that there is no conflict of interests and no fund from any source.

\section{Ethical considerations}

All experiments were carried out at Pharmacology Department, Faculty of Veterinary Medicine, according to the guidelines of the Animal Care and Use Committee, Cairo University (Vet. CU. IACUC, dated September, 2020).

\section{Funding/Support}

This work was financially supported by the authors.

\section{References}

1. Jemal A, Bray F, Center MM, Ferlay J, Ward E, Forman D. Global cancer statistics. CA Cancer J Clin. 2011;61(2):69-90. doi: 10.3322/caac.20107.

2. Amin A, Hamza AA, Bajbouj K, Ashraf SS, Daoud S. Saffron: a potential candidate for a novel anticancer drug against hepatocellular carcinoma. Hepatology. 2011;54(3):857-67. doi: 10.1002/hep.24433.

3. Dong M, Yang G, Liu H, Liu X, Lin S, Sun D, et al. Aged black garlic extract inhibits HT29 colon cancer cell growth via the PI3K/Akt signaling pathway. Biomed Rep. 2014;2(2):250-4. doi: 10.3892/br.2014.226.

4. Subramanian P, Mirunalini S, Dakshayani KB, PandiPerumal SR, Trakht I, Cardinali DP. Prevention by melatonin of hepatocarcinogenesis in rats injected with N-nitrosodiethylamine. J Pineal Res. 2007;43(3):305-12. doi: $\quad$ 10.1111/j.1600-079X.2007.00478.x.

5. Jeong JH, Jeong HR, Jo YN, Kim HJ, Shin JH, Heo HJ. Ameliorating effects of aged garlic extracts against $A \beta$ induced neurotoxicity and cognitive impairment. BMC Complement Altern Med. 2013;13:268. doi: 10.1186/14726882-13-268.

6. Yun HM, Ban JO, Park KR, Lee CK, Jeong HS, Han $\mathrm{SB}$, et al. Potential therapeutic effects of functionally active compounds isolated from garlic. Pharmacol Ther. 2014;142(2):183-95. doi: 10.1016/j.pharmthera.2013.12.005.

7. Uda N, Kashimoto N, Sumioka I, Kyo E, Sumi S, Fukushima S. Aged garlic extract inhibits development of putative preneoplastic lesions in rat hepatocarcinogenesis. J Nutr. 2006;136(3 Suppl):855S-60S. doi: 10.1093/jn/136.3.855S.

8. Duda G, Suliburska J, Pupek-Musialik D. Effects of shortterm garlic supplementation on lipid metabolism and antioxidant status in hypertensive adults. Pharmacol Rep. 
2008;60(2):163-70.

9. Elkayam A, Peleg E, Grossman E, Shabtay Z, Sharabi Y. Effects of allicin on cardiovascular risk factors in spontaneously hypertensive rats. Isr Med Assoc J. 2013;15(3):170-3.

10. Nasri H. Effect of garlic extract on blood glucose level and lipid profile in normal and alloxan diabetic rabbits. Adv Clin Exp Med. 2013;22(3):449-50.

11. Sohn DW, Han CH, Jung YS, Kim SI, Kim SW, Cho YH. Anti-inflammatory and antimicrobial effects of garlic and synergistic effect between garlic and ciprofloxacin in a chronic bacterial prostatitis rat model. Int J Antimicrob Agents. 2009;34(3):215-9. doi: 10.1016/j.ijantimicag.2009.02.012.

12. Zhou L, Mirvish SS. Inhibition by allyl sulfides and crushed garlic of O6-methylguanine formation in liver DNA of dimethylnitrosamine-treated rats. Nutr Cancer. 2005;51(1):68-77. doi: 10.1207/s15327914nc5101_10.

13. Nagini S. Cancer chemoprevention by garlic and its organosulfur compounds-panacea or promise? Anticancer Agents Med Chem. 2008;8(3):313-21. doi: $10.2174 / 187152008783961879$.

14. Zhang CL, Zeng T, Zhao XL, Yu LH, Zhu ZP, Xie KQ. Protective effects of garlic oil on hepatocarcinoma induced by $\mathrm{N}$-nitrosodiethylamine in rats. Int J Biol Sci. 2012;8(3):363-74. doi: 10.7150/ijbs.3796.

15. Chandrashekar PM, Prashanth KV, Venkatesh YP. Isolation, structural elucidation and immunomodulatory activity of fructans from aged garlic extract. Phytochemistry. 2011;72(2-3):255-64. doi: 10.1016/j.phytochem.2010.11.015.

16. Mirabeau TY, Samson ES. Effect of Allium cepa and Allium sativum on some immunological cells in rats. Afr J Tradit Complement Altern Med. 2012;9(3):374-9.

17. Ban JO, Oh JH, Kim TM, Kim DJ, Jeong HS, Han SB, et al. Anti-inflammatory and arthritic effects of thiacremonone, a novel sulfur compound isolated from garlic via inhibition of NF-kappaB. Arthritis Res Ther. 2009;11(5):R145. doi: 10.1186/ar2819.

18. Sivaraman K, Senthilkumar GP, Sankar P, Bobby Z. Attenuation of oxidative stress, inflammation and insulin resistance by allium sativum in fructose-fed male rats. J Clin Diagn Res. 2013;7(9):1860-2. doi: 10.7860/ jcdr/2013/6924.3334.

19. Nasr AY. Protective effect of aged garlic extract against the oxidative stress induced by cisplatin on blood cells parameters and hepatic antioxidant enzymes in rats. Toxicol Rep. 2014;1:682-91. doi: 10.1016/j.toxrep.2014.09.003.

20. Agarwal MK, Iqbal M, Athar M. Garlic oil ameliorates ferric nitrilotriacetate (Fe-NTA)-induced damage and tumor promotion: implications for cancer prevention. Food Chem Toxicol. 2007;45(9):1634-40. doi: 10.1016/j.fct.2007.02.029.

21. Sundaresan S, Subramanian P. S-allylcysteine inhibits circulatory lipid peroxidation and promotes antioxidants in N-nitrosodiethylamine-induced carcinogenesis. Pol J Pharmacol. 2003;55(1):37-42.

22. Bergmeyer HU, Scheibe P, Wahlefeld AW. Optimization of methods for aspartate aminotransferase and alanine aminotransferase. Clin Chem. 1978;24(1):58-73.

23. Roy AV. Rapid method for determining alkaline phosphatase activity in serum with thymolphthalein monophosphate. Clin Chem. 1970;16(5):431-6.

24. Okokon JE, Nwafor PA, Charles U, Dar A, Choudhary MI. Antioxidative burst and hepatoprotective effects of ethanol root extract of Hippocratea africana against paracetamolinduced liver injury. Pharm Biol. 2013;51(7):872-80. doi: 10.3109/13880209.2013.768273.

25. Fernandez A, Sobel C, Goldenberg H. An improved method for determination of serum albumin and globulin. Clin Chem. 1966;12(4):194-205.

26. Stiehl A. [Hyperbilirubinemia in liver diseases]. Fortschr Med. 1982;100(18):842-5. [German].

27. Gibbs PE, Zielinski R, Boyd C, Dugaiczyk A. Structure, polymorphism, and novel repeated DNA elements revealed by a complete sequence of the human alpha-fetoprotein gene. Biochemistry. 1987;26(5):1332-43. doi: 10.1021/ bi00379a020.

28. Pennica D, Nedwin GE, Hayflick JS, Seeburg PH, Derynck R, Palladino MA, et al. Human tumour necrosis factor: precursor structure, expression and homology to lymphotoxin. Nature. 1984;312(5996):724-9. doi: $10.1038 / 312724 \mathrm{a} 0$.

29. Adams PD. Healing and hurting: molecular mechanisms, functions, and pathologies of cellular senescence. Mol Cell. 2009;36(1):2-14. doi: 10.1016/j.molcel.2009.09.021.

30. Ohkawa H, Ohishi N, Yagi K. Assay for lipid peroxides in animal tissues by thiobarbituric acid reaction. Anal Biochem. 1979;95(2):351-8. doi: 10.1016/0003-2697(79)90738-3.

31. Bulaj G, Kortemme T, Goldenberg DP. Ionizationreactivity relationships for cysteine thiols in polypeptides. Biochemistry. 1998;37(25):8965-72. doi: 10.1021/bi973101r.

32. Paglia DE, Valentine WN. Studies on the quantitative and qualitative characterization of erythrocyte glutathione peroxidase. J Lab Clin Med. 1967;70(1):158-69.

33. Spitz DR, Oberley LW. An assay for superoxide dismutase activity in mammalian tissue homogenates. Anal Biochem. 1989;179(1):8-18. doi: 10.1016/0003-2697(89)90192-9.

34. Sinha AK. Colorimetric assay of catalase. Anal Biochem. 1972;47(2):389-94. doi: 10.1016/0003-2697(72)90132-7.

35. Zhang CL, Zeng T, Zhao XL, Xie KQ. Garlic oil attenuated nitrosodiethylamine-induced hepatocarcinogenesis by modulating the metabolic activation and detoxification enzymes. Int J Biol Sci. 2013;9(3):237-45. doi: 10.7150/ ijbs. 5549 .

36. Carleton's histological technique. Ulster Med J. 1967;36(2):172.

37. Li R, Xu L, Liang T, Li Y, Zhang S, Duan X. Puerarin mediates hepatoprotection against CCl4-induced hepatic fibrosis rats through attenuation of inflammation response and amelioration of metabolic function. Food Chem Toxicol. 2013;52:69-75. doi: 10.1016/j.fct.2012.10.059.

38. Parola M, Leonarduzzi G, Biasi F, Albano E, Biocca ME, Poli $\mathrm{G}$, et al. Vitamin E dietary supplementation protects against carbon tetrachloride-induced chronic liver damage and cirrhosis. Hepatology. 1992;16(4):1014-21. doi: 10.1002/ hep. 1840160426.

39. Kweon S, Park KA, Choi H. Chemopreventive effect of garlic powder diet in diethylnitrosamine-induced rat hepatocarcinogenesis. Life Sci. 2003;73(19):2515-26. doi: 10.1016/s0024-3205(03)00660-x.

40. Singh V, Belloir C, Siess MH, Le Bon AM. Inhibition of carcinogen-induced DNA damage in rat liver and colon by garlic powders with varying alliin content. Nutr Cancer. 2006;55(2):178-84. doi: 10.1207/s15327914nc5502_9. 